\title{
The structuring role of free-floating plants on the fish community in a tropical shallow lake: an experimental approach with natural and artificial plants
}

\author{
Franco Teixeira-de Mello - Valdeci Antonio de Oliveira - Simoni Maria Loverde-Oliveira • \\ Vera Lucia M. Huszar · José Barquín • Carlos Iglesias • \\ Thiago Sanna Freire Silva · Carlos Henrique Duque-Estrada • Ana Silió-Calzada • \\ Néstor Mazzeo
}

Received: 13 April 2015/Revised: 29 July 2015/Accepted: 13 August 2015/Published online: 23 October 2015

(C) Springer International Publishing Switzerland 2015

\begin{abstract}
Free-floating plants are important components of aquatic ecosystems in tropical climates, playing a key role in the structure and spatial distribution of fish communities. This study aims at elucidating the potential effects of free-floating vegetation on fish community structure in a tropical floodplain lake, using an experimental approach based on natural and artificial devices (Eichhornia crassipes), in high and low (LT) turbidity waters. A total of 32 fish species were found, richness, abundance, biomass, mean fresh body weight, and standard length were all significantly higher in the LT regions.
\end{abstract}

Guest editors: M. Beklioğlu, M. Meerhoff, T. A. Davidson, K. A. Ger, K. E. Havens \& B. Moss / Shallow Lakes in a Fast Changing World

Electronic supplementary material The online version of this article (doi:10.1007/s10750-015-2447-2) contains supplementary material, which is available to authorized users.

F. Teixeira-de Mello $(\bowtie) \cdot$ C. Iglesias · N. Mazzeo Departamento de Ecología Teórica y Aplicada,

CURE-Facultad de Ciencias, Universidad de la República,

Maldonado, Uruguay

e-mail: frantei@fcien.edu.uy

V. A. de Oliveira $(\bowtie) \cdot$ S. M. Loverde-Oliveira Departamento de Ciências Biológicas, Universidade Federal de Mato Grosso, Rondonópolis, MT, Brazil e-mail: valdeciantonio2009@ hotmail.com

\section{L. M. Huszar}

Museu Nacional, Universidade Federal do Rio de Janeiro, Rio de Janeiro, RJ, Brazil
Although no significant differences of community traits were found between artificial and natural substrates, regardless of water turbidity, fish composition differences between devices were observed in clear waters. Benthivorous fishes were the most widespread trophic group, with higher abundance and biomass in LT, while no differences were found among plant types. The results confirmed the structural role played by free-floating plants in the fish community by offering a refuge to smaller bodied fish species and younger specimens of larger species, independently of turbidity conditions. However, the effect was stronger in clear waters. The evidence also supported the hypothesis that the fish community forages within the plant beds. Turbidity spatial gradients or turbid regimes in tropical shallow lakes, as well as important

\author{
J. Barquín · A. Silió-Calzada \\ Environmental Hydraulics Institute, Universidad de \\ Cantabria, Santander, Spain \\ T. S. F. Silva \\ Departamento de Geografia, Instituto de Geociências e \\ Ciências Exatas, UNESP - Univ. Estadual Paulista, \\ Rio Claro, SP, Brazil \\ C. H. Duque-Estrada \\ Departamento de Biologia, Instituto de Ciências \\ Biológicas, Universidade Federal de Juiz de Fora, \\ Juiz de Fora, MG, Brazil
}


floating macrophyte coverage could have strong impacts on the fish community structure.

Keywords Trophic interactions - Predation refuge Food resources · Tropical floodplain · Pantanal · Brazil

\section{Introduction}

Aquatic plants play a fundamental role in freshwater ecosystems by affecting biological interactions, several physical and chemical processes, with potential influences for the entire ecosystem functioning (Carpenter \& Lodge, 1986; Jeppesen et al., 1997). For example, submerged macrophytes directly compete with phytoplankton for resources (light and nutrients), provide refuge for zooplankton and influence fish community structure generating several feedback mechanisms that promote clear water regimes in shallow lakes (Scheffer \& Carpenter, 2003). In contrast, the role of larger freefloating plants (e.g., Eichhornia, Pistia or Pontederia spp.) is still poorly understood (Meerhoff et al., 2003; Meerhoff \& Mazzeo, 2004; Bicudo et al., 2007; Meerhoff et al., 2007a, b; Teixeira-de Mello et al., 2009), particularly regarding the biological interactions among free-floating plants, zooplankton and fish (Carniatto et al., 2012; Evangelista et al., 2014; MontielMartínez et al., 2015) and the consequences at an ecosystem level (Sanseverino et al., 2012).

Free-floating plants are capable of developing very high biomass and covering large areas in subtropical and tropical lakes, with important consequences for the whole ecosystem functioning. Dominance of freefloating plants generate anoxic and dark conditions and promote phosphate and ammonium release from sediments, affecting biological communities and causing extensive fish kills (Miranda et al., 2000; De Tezanos Pinto \& O'Farrell, 2014). These effects tend to be less drastic when free-floating plants occupy only the littoral zone, but they may still have important consequences for the whole ecosystem (Villamagna \& Murphy, 2010). In this later case, free-floating plant beds have been reported to host higher abundances and a higher diversity of fish species in floodplain rivers (Agostinho et al., 2007), floodplain lakes (Scarabotti et al., 2011; Gomes et al., 2012), and shallow lakes (Meerhoff et al., 2003, 2007a; Pacheco \& Da-Silva, 2009; Teixeira-de Mello et al., 2009), also influencing the feeding habitat of fishes (Sazima \& Zamprogno,
1985; Padial et al., 2009; Ximenes et al., 2011). Moreover, when wind or flooding promote the movement of floating mats of Eichhornia crassipes, these "moving islands" may transport the smaller fish sheltered in their roots (Sazima \& Zamprogno, 1985). Thus, when freefloating plants are present but not dominant in a lake they might be exerting an important role on ecosystem functioning through their effect on fish communities.

Fish communities can also be affected by physical in-lake factors, such as temperature, turbulence, and water transparency (Stoner, 2004), which modulate their habitat use and activity levels. Low water transparency may differentially influence species composition, trophic, and size groups of fish communities. For example, turbidity can positively affect larval fish and planktivorous fishes. These fishes have a short visual field and attack distance, and thus, under higher turbidity conditions they could hide better and get closer to their prey and have a higher chance of effective catches (Utne-Palm, 2002; De Robertis et al., 2003). Additionally, piscivorous fishes, which have a larger attack distance, might be negatively affected by high turbidity conditions, what will reduce prey pressure on the smaller fishes (Aksnes \& Giske, 1993; Pekcan-Hekim \& Lappalainen, 2006). Freefloating plants and relevant spatial gradients of turbidity levels co-occur in ecosystems from tropical floodplains, leading to complex interaction among free-floating plants, turbidity, and fish communities.

In this paper, we experimentally evaluated the role of free-floating plants on shaping fish communities in two contrasting water transparency scenarios. To distinguish structural effects from other types of interactions between aquatic plants and fish assemblages, our experimental design considered both natural and artificial substrates. Briefly, we aimed to answer: (i) what is the role of floating plants in fish community structure in a tropical lake? (ii) how does water transparency modify fish community structure in floating plants? and (iii) is the effect of floating vegetation mostly structural or do effects differ between natural and artificial plant mats?

\section{Methods}

Study area

The Brazilian Pantanal is an extensive wetland area $\left(\sim 140,000 \mathrm{~km}^{2}\right)$ spanning the states of Mato Grosso 
and Mato Grosso do Sul, in central South America. This wetland is located at a large intra-continental depression drained by the Paraguay River (Junk et al., $2011,2014)$, with a hydraulic gradient varying from 0.7 to $6.5 \mathrm{~cm} \mathrm{~km}^{-1}$ (Ponce, 1995). The area contains a large number of shallow lakes with seasonal (recurring) water level fluctuations. The complex hydrography of the region, together with the geomorphologic and edaphic heterogeneity, shapes a patchwork of landscapes with different hydrological conditions (PCBAP, 1997). The annual flood pulse results in an extensive area covered by $0.4-1.0 \mathrm{~m}$ high water levels, depending on the proximity to main rivers or associated streams. The regional tropical climate is warm and wet during summer, and mild-cold and dry during winter (Koeppen Aw updated in Kottek et al. 2006), with a total annual precipitation ranging from 800 to $1,600 \mathrm{~mm}$ and a mean annual temperature of $27^{\circ} \mathrm{C}$ (PCBAP, 1997). The high water level phase comprises the period between February and April, while the low water phase occurs between July and October.

The present study was conducted in Sinhá Mariana, a shallow lake located in the northern region of the Pantanal $\left(16^{\circ} 20^{\prime} \mathrm{S}, 55^{\circ} 54^{\prime} \mathrm{W}\right.$, Mato Grosso State, Brazil), on the left bank of the Cuiabá River, a tributary of the Paraguay River, one of the main rivers in the Paraná watershed. Sinhá Mariana is an elongated, permanent lake, with an area of $11 \mathrm{~km}^{2}$ during the low water phase, a maximum depth of $4.7 \mathrm{~m}$, and an average depth of $3.6 \mathrm{~m}$ (Pinto, 1999; Loverde-Oliveira \& Huszar, 2007). The morphometry of the lake is originated from an enlargement of the Mutum River channel, a clear water river with a moderate concentration of humic substances (locally referred to as "black water"; Nunes \& Da-Silva, 2009), and is linked with the turbid (extremely high suspended matter content) Cuiabá River even during low water phases. Sinhá Mariana is also connected to the large and adjacent turbid water Chacororé Lake, forming a wide flooded area of $450 \mathrm{~km}^{2}$ (Fig. 1). Consequently, Sinhá Mariana has a strong turbidity gradient from east (Mutum River inlet) to west (Cuiabá River inlet/outlet). The surrounding landscape of Sinhá Mariana is flat and open and is covered by short, savanna-like vegetation subjecting the lake to constant wind action, and is predominantly used for cattle breeding. The coastal zone is covered by aquatic macrophytes, mainly Eichhornia azurea (Swartz) Kunth, E. crassipes (Martens) Solms, Pontederia parviflora Alexander, Oxycaryum cubense (Poeppig \& Kunth) Lye, Panicum laxum Swartz and Neptunia cf. prostrata (Lamarck) Baillon.

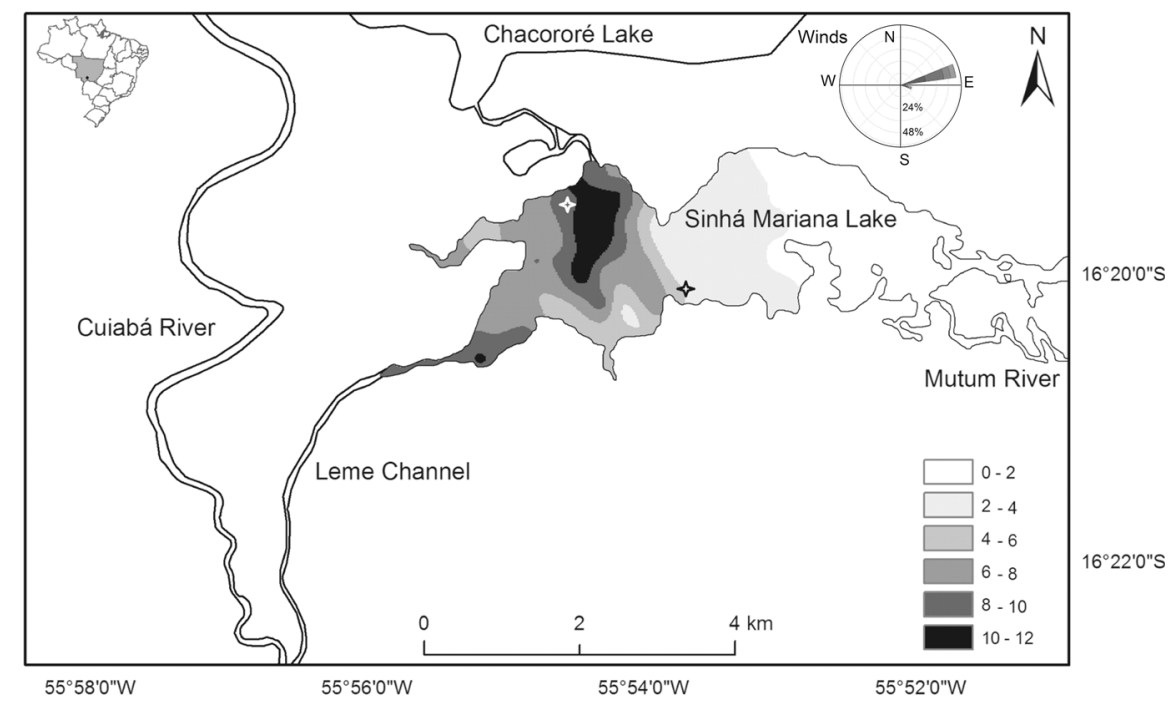

Fig. 1 Map of Sinhá Mariana Lake (Mato Grosso, Brazil), showing the water turbidity gradient from east (Mutum River) to west (Cuiabá River) during the high water season (unpublished data), as well as the location of the experimental plant beds (modules, diamonds). Turbidity is presented in nephelometric turbidity units and shown in two unit intervals. Darker areas indicate higher turbidity. Above and right shown the predominant wind direction during the experiment period (FebruaryMarch 2013) 
Experimental and sampling design

During February/March 2013 (high water level period), we installed natural $(n=12)$ and artificial $(n=12)$ free-floating plant beds in open modules, in shallow (1-1.5 m depth) areas close to the littoral zone. These modules were evenly located in two different regions with high and low water turbidity levels (turbidity differences were higher than 50\%, Fig. 1). For the selection of sites in clear and turbid waters, we considered open water zones located at least $10 \mathrm{~m}$ apart from the edge of natural plants beds, with a depth of approximately $1.0 \mathrm{~m}$, without the presence of submerged plants. These criteria were used because differences in such conditions affect habitat structure and can therefore affect the fish community (Meerhoff et al., 2007a; Teixeira-de Mello et al., 2009; Dibble \& Pelicice, 2010). Finally, the experimental sites include similar regions in terms of fetch (Fig. 1), maximizing the spatial turbidity gradients (conditioned by the main tributaries: Mutum river and Chacororé connection) without important differences in terms of wave effects. Predominant winds had between 0.5 and $3.6 \mathrm{~m} \mathrm{~s}^{-1}(52.5 \%)$ and a higher frequency of calms $\left(32.5 \%, 0 \mathrm{~m} \mathrm{~s}^{-1}\right)$, with a predominant direction ENE.

Natural and artificial plants were intercalated 10 meters apart from each other. Each plant bed $(1 \mathrm{~m}$ diameter module) consisted of floating PVC plastic rings anchored to the bottom with a net, where natural or artificial plants where placed. The natural plant treatment consisted of 10 individuals of Eichhornia crassipes per unit, collected from surrounding floating islands. They were selected to obtain a final plant coverage of $100 \%$. Plant roots were rinsed to remove sediments and associated fauna (fish and aquatic macroinvertebrates). The artificial plant modules were designed based on previous studies (for a full descripction see: Meerhoff et al., 2007a) and comprised 24 artificial plants shaped similar to E. crassipes external morphology. Each artificial plant consisted of a plastic plate of $18 \mathrm{~cm}$ diameter, with Christmas garland decorations used as "roots". Each plastic plate had 16 "roots" of $25 \mathrm{~cm}$ attached, with $1.5 \mathrm{~cm}$ long "root hairs". Both natural and artificial plant beds were left for 30 days for natural colonization by periphyton and macroinvertebrates before sampling. Several modules were lost due to wave and wind action (in clear and turbid regions), and also for floating island displacement, yielding a final replication of four natural and three artificial modules of turbid waters, and five replicates each for both natural and artificial modules in clear waters $\left(n_{\text {turbid }}=7, n_{\text {clear }}=10\right)$.

Fish associated with each habitat module were sampled during nighttime (following Teixeira-de Mello et al., 2009), with a cylindrical net (1.2 $\mathrm{m}$ in diameter, mesh size of $0.3 \mathrm{~cm}$ ) attached to two small boats and dropped to the lake bottom under each plant module. The net was then quickly pulled up by moving the boats, enclosing the entire plant module and bringing it to the surface. This procedure allowed the acquisition of quantitative community information per unit area. All captured fish were euthanized using 2-phenoxi-ethanol $\left(1 \mathrm{ml} \mathrm{l}^{-1}\right)$, taxonomically identified to species level (Britski et al., 2007), measured (standard length SL, cm) for analysis of individual mean body length $(\mathrm{cm})$ and weighed (fresh weigh $\mathrm{FW}, \mathrm{g}$ ) for analysis of individual mean body weight $(\mathrm{g})$ and for total biomass $\left(\mathrm{g} \mathrm{m}^{-2}\right)$. Reference fish species was fixed in formalin $10 \%$.

The gut of most captured individuals (158 out of 165) was dissected in the field and fixed in ethanol $\left(95^{\circ}\right)$, then the gut content was later analyzed in the laboratory. Food items were classified as "vegetal matter" (i.e., macrophytes + periphyton + algae), "aquatic invertebrates" (i.e., Insecta: Trichoptera and Coleoptera; Diptera: Ceratopogonidae, Chironomidae and Chaoboridae; Hemiptera; Hirudinea; Acari; Bivalvia and Nematoda), and "other animal remains" (invertebrate remains that could not be identified taxonomically).

The absolute volume and relative proportion of each food item in relation to each analyzed fish gut were estimated, using a binocular stereomicroscope $(50 \times)$ and a millimetric grid plate (assuming a fixed height of one millimeter to estimate volume content as $\mathrm{mm}^{3}$ ). To control the effect of fish size effect on the quantity of food consumed, the consumed amount (in $\mathrm{mm}^{3}$ ) was corrected by individual fresh weigh. The means of the absolute and relative amounts of each food type consumed in artificial and natural plant beds and in clear and turbid waters were also calculated at the individual level.

Following Teixeira-de Mello et al. (2009), each fish was assigned to one of the following trophic groups, based on gut content composition: (a) benthivorous (more than $90 \%$ of aquatic macroinvertebrates); (b) omni-benthivorous (aquatic macroinvertebrates as main item and more than $10 \%$ vegetal matter); 
(c) omni-herbivorous (vegetal matter as main food item and more than $10 \%$ aquatic macroinvertebrates), herbivorous (more than $90 \%$ vegetal matter); (d) detritivorous (more than $90 \%$ of organic matter/detritus); and e) piscivorous (more than $90 \%$ fish tissue). To evaluate the trophic composition of each plant module, each sampled individual fish was assigned to the most appropriate trophic group, regardless of species.

\section{Statistical analysis}

Fish richness, abundance, biomass, trophic groups, and diet (total volume and relative volume) were analyzed using analysis of variance (two-way ANOVA), with plant type (two levels: natural and artificial) and water transparency (two levels: high and low turbidity, namely in the text as clear and turbid waters) as fixed factors. Interaction terms (transparency $\times$ plant type) were included in all models. Prior to the analysis, we tested the assumptions of normal distribution (Kolmogorov-Smirnoff test) and homoscedasticity of the residuals (Levene's test). In any case was necessary a numerical transformation of the data. Tukeýs post hoc (for Unequal $N$ ) tests were applied when statistically interaction were detected by the two-way ANOVA. The size class was analyzed considering the cumulative mean of the relative abundance of each size class.

Cluster analysis was used to explore (dis)similarity patterns in fish species composition and abundance (ind $\mathrm{m}^{-2}$ ) among the treatments. The Jaccard similarity index, with a paired group algorithm, was used for species composition (presence-absence) matrices. The Bray-Curtis similarity index, with a paired group algorithm, was applied to the species composition and abundance (ind $\mathrm{m}^{-2}$ ) matrix. The statistical significance of (dis)similarities between the four possible combinations of treatments (natural and artificial, clear, and turbid waters) was tested using one-way analysis of similarity (one-way ANOSIM), with 9.999 permutations, using a sequential Bonferroni correction. All data analyses were performed using the PAST software (Hammer et al., 2001).

\section{Results}

A total of 32 fish species were captured. Fish assemblages within the plant beds were characterized by the occurrence of small bodied individuals ( $4.6 \mathrm{~cm} \pm 0.2 \mathrm{SE}$ ), belonging to 24 small species, or juveniles of larger species (8 spp: Hypostomus sp., Leporinus friderici, Leporellus vittatus, Pimellodus maculatus, Rhinelepis sp., Schizodon borelli, Serrasalmus maculatus, and Synbranchus marmoratus; Fig. 2).

Only eight of the sampled species were shared between the two zones (clear and turbid waters), but with different abundances (Fig. 2). Six species were exclusively captured in the turbid water zone, while 18 were caught in the clear water zone (Fig. 2 and Appendix I, Supplementary material). Differences in species composition were less evident for each plant type, 14 species were only captured in natural plants, and 7 species only in artificial plants. Finally, 11 species were shared between both plant types (Appendix I, Supplementary material).

Regardless of plant type, the cumulative means of the relative abundances of size classes showed that the smaller bodied fishes ( $\leq 5 \mathrm{~cm} \mathrm{SL}$ ) comprised $96 \%$ of the individuals sampled in turbid waters, while they represented only $63.4 \%$ of the individuals in clear waters. Thus, a higher mean body length was found for the clear water environments (Fig. 3). The proportion of smaller bodied fishes did not vary significantly between natural and artificial plants, at either turbid or clear waters (100 vs. $93.8 \%$ and 64.4 vs. $60.5 \%$, respectively).

Significantly higher species richness, abundance, biomass, mean individual body fresh weight, and mean body length were found in clear versus turbid waters, regardless of substrate type (Table 1). Significant differences between natural and artificial plants, however, were found only for fish biomass in clear waters (Table 1).

Significant differences between clear and turbid water communities were also found for fish species composition $(R$ anosim $=0.69, P<0.0001)$ and species composition and abundance $(R$ anosim $=$ 0.74, $P<0.0001$ ). Moreover, significant differences in species composition and abundance were detected between natural and artificial plants in clear water (pairwise comparison, $P<0.05$ ). In turbid waters, significant differences between plant type were only registered for fish species composition (pairwise comparison, $P<0.05$; Fig. 4).

Dietary analysis evidenced the presence of four trophic groups (benthivorous, herbivorous, omni- 
Fig. 2 Species abundance (ind $\mathrm{m}^{-2}$ ) in clear and turbid waters. Species are ranked in decreasing order of abundance in clear waters. Mean $\pm 1 \mathrm{SE}$

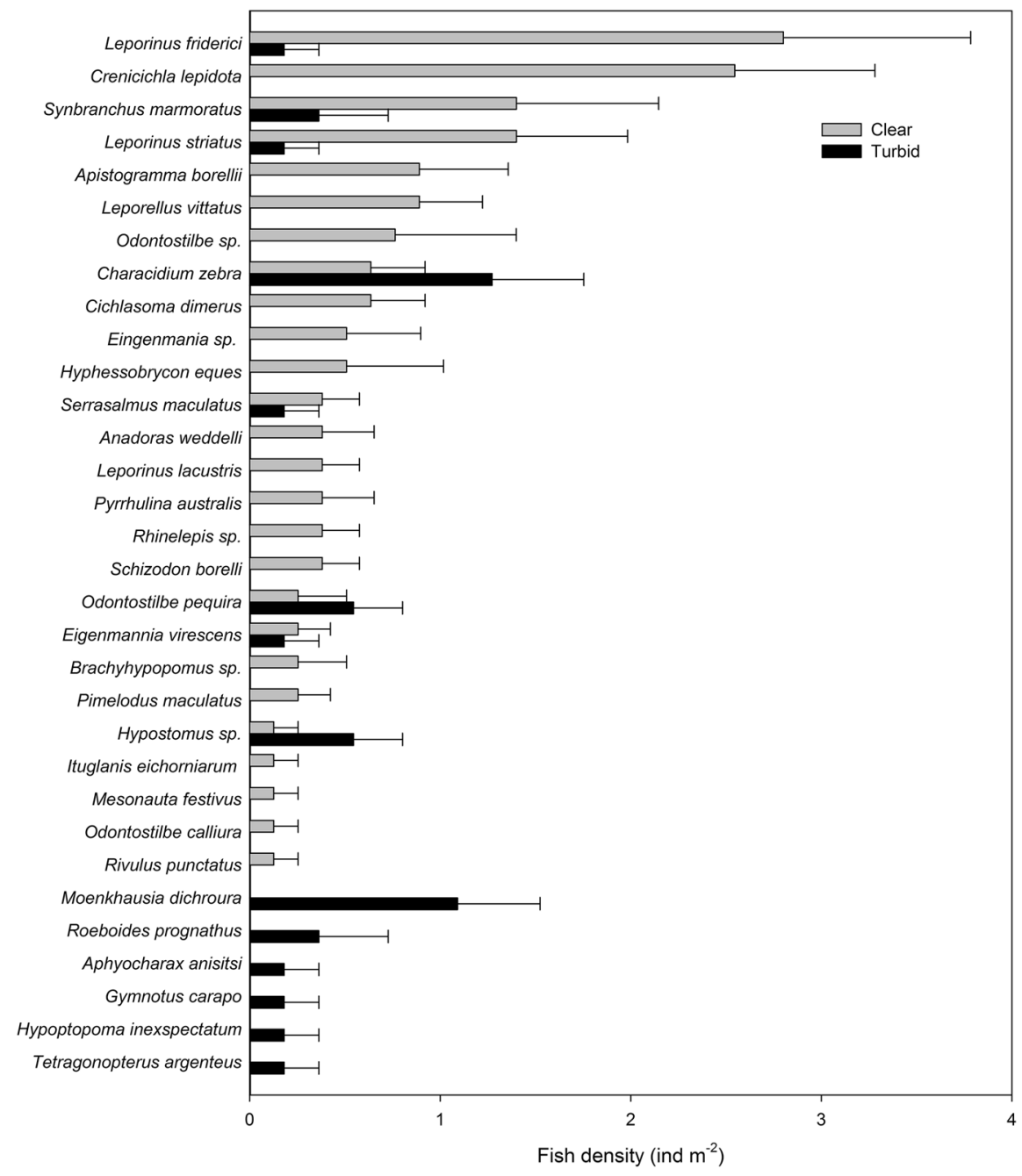

benthivorous, and omni-herbivorous), while detritivorous and piscivorous fishes were absent within the plant beds. Moreover, zooplankton was not found as a food resource for the sampled fish. The benthivorous trophic group was the most abundant group, with higher abundance (two-way ANOVA, $F=11.13, P<0.01$ ) and biomass in clear than in turbid waters (two-way ANOVA, $F=14.42, P<0.01$ ). No statistical differences between natural and artificial plant types were observed (Table 2). Remarkably, individuals belonging to the same species were often sorted into different trophic groups according to their gut content, a pattern observed for several species (Table 3).

Main food items included Insecta (recognizable plus animal remains) and vegetal material (macrophytes and periphyton, Table 4). The variety of food items was higher in clear waters than in turbid waters (11 vs. 7 , respectively). The higher fish abundance and biomass registered for clear water conditioned the observed higher amount of total food, animal (recognizable plus animal remains) and vegetal food items in comparison with the turbid water values (two-way ANOVA, $F=4.98, P<0.05)$. However, when the food amount was expressed as a function of individual fish biomass, no differences between clear and turbid waters or between artificial and natural plants were detected (Table 4).

\section{Discussion}

This study confirmed the structural role of freefloating plants on shaping fish communities, offering 


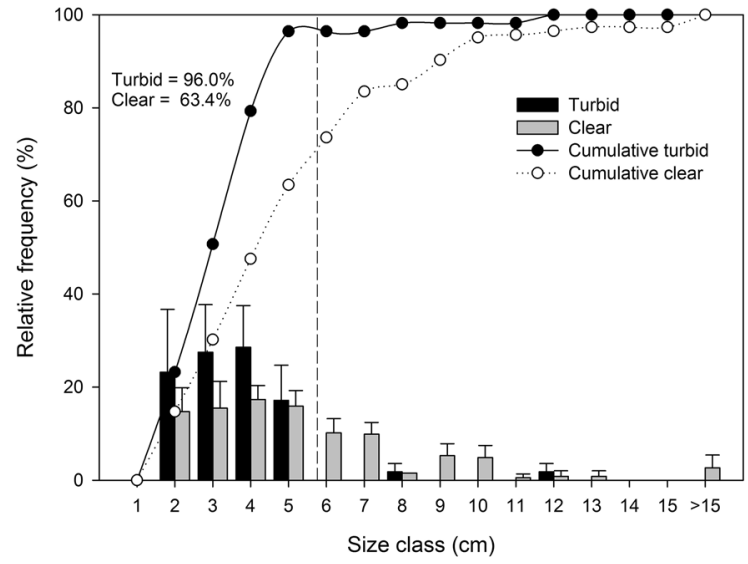

Fig. 3 Relative frequency of individual fish length, considering artificial and natural plants together. The dashed vertical line separates species according to the body length $(\leq 5 \mathrm{~cm}$ standard length SL to the left). Mean $\pm 1 \mathrm{SE}$

refuge to smaller bodied fish species and younger specimens of larger species, in both turbid and clear waters. Fish richness, abundance, biomass, and individual body length were all higher in clear water environments. The field experiment confirmed that the free-floating plant beds host a high abundance and diversity of fish species as previous references indicated for different freshwater ecosystems (Meerhoff et al., 2003; Agostinho et al., 2007; Meerhoff et al., 2007a; Pacheco \& Da-Silva, 2009; Teixeira-de Mello et al., 2009; Scarabotti et al., 2011; Gomes et al., 2012).

Water turbidity also affects the fish community structure in the pelagic zone. Pelagic fish communities showed a notorious difference in species composition, abundance and size distribution between clear and turbid waters (Teixeira-de Mello, unpublished data, Appendix II). Additionally, the pelagic community was completely different from the community collected below the free-floating plants in clear as well as turbid conditions. Considering that the pelagic and plant-bed communities only shared single species, and the higher diversity of fish species observed in plant beds in comparison with the pelagic zone (32 vs. 12 , respectively), we can support the strong physical effect of free-floating plants on the fish community. Moreover, considering that we recorded the same number of species for clear and turbid pelagic waters, the effect of floating plants on species richness was stronger in clear water conditions. In terms of abundance, a similar pattern was found. However, the effect of plant beds on the mean fish body size $(\mathrm{cm})$ was higher in turbid than in clear waters. In turbid waters, fishes were five times larger in the pelagic zone than in plant beds (see Tables 1 and 4). In this sense, the pelagic fish community in turbid waters had a strong contribution of piscivorous fishes $(50 \%)$ that could explain the absence of small fishes in turbid pelagic zones, contrasting the higher abundance observed in clear waters.

The experimental results allows us to hypothesize that the use of plants by small fish species is a potential mechanism for avoiding predation, and can be affected by water turbidity. Previous studies have suggested that turbidity per se can provide a shelter effect for fish communities in temperate (Pekcan-Hekim \& Lappalainen, 2006) and subtropical systems (Gelós et al., 2010). Furthermore, smaller-sized individuals were found in the turbid module indicating that smaller bodied individuals also prefer to occupy the plant beds in supposedly safer zones created by the higher turbidity.

Free-floating macrophytes have also been reported as a feeding habitat for fishes, due to the presence of

Table 1 Mean \pm standard error of fish community attributes of natural and artificial plants

\begin{tabular}{|c|c|c|c|c|c|c|}
\hline & \multicolumn{3}{|l|}{ Clear waters } & \multicolumn{3}{|c|}{ Turbid waters } \\
\hline & Natural & Artificial & Mean & Natural & Artificial & Mean \\
\hline Abundance (ind $\mathrm{m}^{-2}$ )* & $14.5 \pm 3.1^{\mathrm{A}}$ & $19.6 \pm 3.8^{\mathrm{A}}$ & $17.1 \pm 2.5$ & $6.7 \pm 2.2^{\mathrm{B}}$ & $4.7 \pm 1.1^{\mathrm{B}}$ & $5.8 \pm 1.1$ \\
\hline Biomass $\left(\mathrm{g} \mathrm{m}^{-2}\right)^{*}$ & $25.7 \pm 6.8^{\mathrm{A}}$ & $46.4 \pm 4.4^{\mathrm{B}}$ & $36.1 \pm 5.1$ & $5.8 \pm 2.2^{\mathrm{C}}$ & $2.9 \pm 1.2^{\mathrm{C}}$ & $4.6 \pm 1.2$ \\
\hline Richness* & $6.8 \pm 1.4^{\mathrm{A}}$ & $7.2 \pm 1.0^{\mathrm{A}}$ & $7.0 \pm 0.8$ & $4.5 \pm 1.3^{\mathrm{B}}$ & $2.7 \pm 0.3^{\mathrm{B}}$ & $3.7 \pm 0.7$ \\
\hline Mean body length $(\mathrm{cm})^{*}$ & $5.6 \pm 0.6^{\mathrm{A}}$ & $4.5 \pm 0.3^{\mathrm{A}}$ & $5.0 \pm 0.4$ & $3.1 \pm 0.8^{\mathrm{B}}$ & $3.4 \pm 0.4^{\mathrm{B}}$ & $3.2 \pm 0.4$ \\
\hline Mean body fresh weight $(\mathrm{g})^{*}$ & $1.8 \pm 0.2^{\mathrm{A}}$ & $2.7 \pm 0.5^{\mathrm{A}}$ & $2.3 \pm 0.3$ & $0.8 \pm 0.4^{\mathrm{B}}$ & $0.6 \pm 0.2^{\mathrm{B}}$ & $0.8 \pm 0.2$ \\
\hline
\end{tabular}

* Indicates $P<0.05$ significance in the two-way ANOVA. Significant $(P<0.05)$ differences between groups are shown by different letters (A and $\mathrm{B})$ 
Fig. 4 Cluster analysis of fish community structure in natural (Nat) and artificial (Art) plant beds, in clear (C) and turbid (T) waters. Left panel sorting of plant modules according to species composition (presence/absence); and right panel sorting of plant modules according to fish species composition and abundance (ind $\mathrm{m}^{-2}$ )

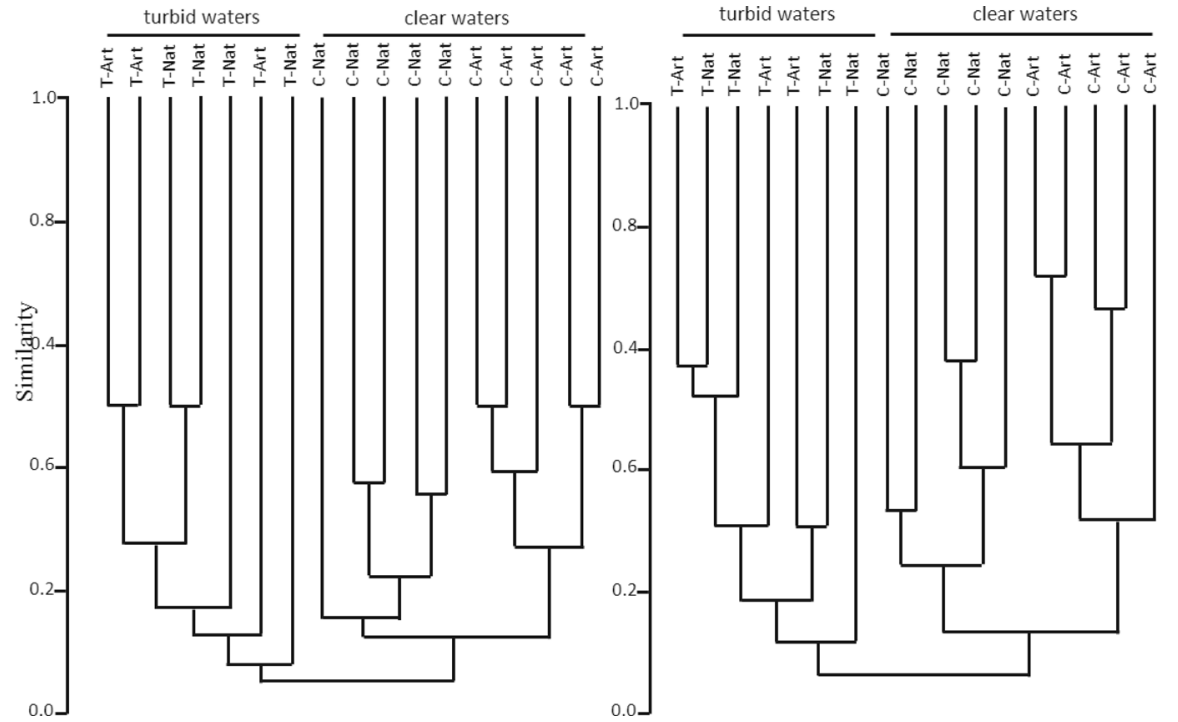

Table 2 Abundance (ind $\left.\mathrm{m}^{-2}\right)$ and biomass $\left(\mathrm{g} \mathrm{m}^{-2}\right)$ of the trophic groups identified in clear and turbid waters, and in natural and artificial plant beds

\begin{tabular}{|c|c|c|c|c|c|c|}
\hline & \multicolumn{3}{|l|}{ Clear waters } & \multicolumn{3}{|c|}{ Turbid waters } \\
\hline & Natural & Artificial & Mean & Natural & Artificial & Mean \\
\hline \multicolumn{7}{|l|}{ Abundance } \\
\hline Benthivorous* & $11 \pm 2^{\mathrm{A}}$ & $11 \pm 3^{\mathrm{A}}$ & $11 \pm 2$ & $4 \pm 1^{\mathrm{B}}$ & $3 \pm 1^{\mathrm{B}}$ & $3 \pm 1$ \\
\hline Herbivorous & $2 \pm 1$ & $3 \pm 1$ & $3 \pm 1$ & $1 \pm 1$ & $1 \pm 0$ & $1 \pm 1$ \\
\hline Omni-benthivorous & $1 \pm 1$ & $1 \pm 0$ & $1 \pm 1$ & $1 \pm 1$ & 0 & $1 \pm 0$ \\
\hline Omni-herbivorous & $1 \pm 1$ & $2 \pm 1$ & $1 \pm 0$ & 0 & 0 & 0 \\
\hline \multicolumn{7}{|l|}{ Biomass } \\
\hline Benthivorous* & $20.9 \pm 6.2^{\mathrm{A}}$ & $23.9 \pm 6.0^{\mathrm{A}}$ & $22.4 \pm 4.1$ & $2.1 \pm 1.2^{\mathrm{B}}$ & $2.1 \pm 1.4^{\mathrm{B}}$ & $2.1 \pm 0.8$ \\
\hline Herbivorous & $9.8 \pm 6.1$ & $6.1 \pm 4.1$ & $7.9 \pm 3.5$ & $0.9 \pm 0.9$ & $0.6 \pm 0.4$ & $0.8 \pm 0.5$ \\
\hline Omni-benthivorous & $2.7 \pm 2.7$ & $4.6 \pm 2.9$ & $3.7 \pm 1.9$ & $2.4 \pm 2.2$ & 0 & $1.4 \pm 1.3$ \\
\hline Omni-herbivorous & $2.2 \pm 2.0$ & $2.6 \pm 1.7$ & $2.4 \pm 1.2$ & $0.1 \pm 0.1$ & 0 & $0.03 \pm 0.03$ \\
\hline
\end{tabular}

Mean \pm 1 SE of natural and artificial plants

* Indicates $P<0.05$ significance in the two-way ANOVA. Significant $(P<0.05)$ differences between groups are shown by different letters (A and B)

diverse food items (Sazima \& Zamprogno, 1985; Padial et al., 2009; Ximenes et al., 2011). According to the gut contents found in the present study, the hypothesis that the fish community is feeding within the plant beds is also supported. In both turbid and clear waters, fish fed mainly on aquatic macroinvertebrates associated with the aquatic plants, but also on vegetal material, mainly periphyton on both artificial and the natural plants. In addition, water transparency had no effect on the amount of food consumed per fish biomass, or on trophic group composition. These results agree with the idea that the food available within macrophytes beds is a second mechanism affecting the use of these plants by small fishes. Our results demonstrated the clear importance of macroinvertebrates as a food source in this tropical system, and according to previous results, the amount of macroinvertebrate intake by fishes was not necessarily affected by the turbidity (Figueiredo et al., 2015). Our data also confirmed that an omnivorous feeding behavior seems to be common, as previously suggested (GonzálezBergonzoni et al., 2012), even when considering only 
Table 3 Trophic classification of fish species captured inside the plant beds according to gut content analysis

\begin{tabular}{|c|c|c|c|c|}
\hline & Benthivorous & Herbivorous & Omni-herbivorous & Omni-benthivorous \\
\hline Crenicichla lepidota & $\sqrt{ }$ & $\sqrt{ }$ & $\sqrt{ }$ & $\sqrt{ }$ \\
\hline Leporinus friderici & $\sqrt{ }$ & $\sqrt{ }$ & $\sqrt{ }$ & $\sqrt{ }$ \\
\hline Leporinus striatus & $\sqrt{ }$ & $\sqrt{ }$ & $\sqrt{ }$ & $\sqrt{ }$ \\
\hline Moenkhausia dichroura & $\sqrt{ }$ & $\sqrt{ }$ & $\sqrt{ }$ & $\sqrt{ }$ \\
\hline Odontostilbe pequira & $\sqrt{ }$ & $\sqrt{ }$ & $\sqrt{ }$ & $\sqrt{ }$ \\
\hline Characidium zebra & $\sqrt{ }$ & $\sqrt{ }$ & $\sqrt{ }$ & $\sqrt{ }$ \\
\hline Cichlasoma dimerus & $\sqrt{ }$ & $\sqrt{ }$ & $\sqrt{ }$ & $\sqrt{ }$ \\
\hline Leporinus lacustris & $\sqrt{ }$ & $\sqrt{ }$ & $\sqrt{ }$ & $\sqrt{ }$ \\
\hline Rhinelepis sp. & & $\sqrt{ }$ & $\sqrt{ }$ & \\
\hline Anadoras weddelli & $\sqrt{ }$ & & & \\
\hline Aphyocharax anisitsi & $\sqrt{ }$ & & & \\
\hline Apistogramma borellii & $\sqrt{ }$ & & & \\
\hline Brachyhyроротиs sp. & $\sqrt{ }$ & & & \\
\hline Eigenmannia virescens & $\sqrt{ }$ & & & \\
\hline Eingenmania sp. & $\sqrt{ }$ & & & \\
\hline Gymnotus carapo & $\sqrt{ }$ & & & \\
\hline Hyphessobrycon eques & $\sqrt{ }$ & & & \\
\hline Ituglanis eichorniarum & $\sqrt{ }$ & & & \\
\hline Leporellus vittatus & $\sqrt{ }$ & & & \\
\hline Odontostilbe calliura & $\sqrt{ }$ & & & \\
\hline Pimelodus maculatus & $\sqrt{ }$ & & & \\
\hline Pyrrhulina australis & $\sqrt{ }$ & & & \\
\hline Rivulus punctatus & $\sqrt{ }$ & & & \\
\hline Schizodon borelli & $\sqrt{ }$ & & & \\
\hline Synbranchus marmoratus & $\sqrt{ }$ & & & \\
\hline Tetragonopterus argenteus & $\sqrt{ }$ & & & \\
\hline Hypostomus sp. & & $\sqrt{ }$ & & \\
\hline Leporellus vittatus & & $\sqrt{ }$ & & \\
\hline Mesonauta festivus & & $\sqrt{ }$ & & \\
\hline Schizodon borelli & & $\sqrt{ }$ & & \\
\hline Synbranchus marmoratus & & $\sqrt{ }$ & & \\
\hline Serrasalmus maculatus & & & $\sqrt{ }$ & \\
\hline Serrasalmus sp. & & & $\sqrt{ }$ & \\
\hline Roeboides prognathus & & & & $\sqrt{ }$ \\
\hline
\end{tabular}

Please note that several species were assigned to different trophic groups because of differences in gut content between individuals of the same species. Omni omnivorous

the fish community composition associated with the plants beds. The remarkable differences in fish abundance and biomass in plant beds (between clear and turbid regions) indicate that total food consumption was higher in clear waters, affecting the total periphyton consumption, and increasing the predation pressure on macroinvertebrates.
Contrary to our expectations based on previous works in shallow lakes (Meerhoff et al., 2012) predicting that high-temperature, plant-associated fish communities might be characterized by higher abundances and smaller-sized individuals, we observed that fish abundance was lower and fish body length larger here than in subtropical systems (Teixeira-de 
Table 4 Mean values of total volume $\left(\mathrm{mm}^{3}\right) \pm$ standard error for each food item registered in fish gut contents from clear and turbid waters, and from both artificial and natural plant modules

\begin{tabular}{|c|c|c|c|c|}
\hline & \multicolumn{2}{|l|}{ Clear waters } & \multicolumn{2}{|l|}{ Turbid waters } \\
\hline & Artificial & Natural & Artificial & Natural \\
\hline \multicolumn{5}{|l|}{ Insecta } \\
\hline Coleoptera & $23 \pm 22$ & $6 \pm 4$ & $30 \pm 30$ & $18 \pm 10$ \\
\hline Trichoptera & $64 \pm 58$ & $61 \pm 52$ & $1 \pm 1$ & $1 \pm 1$ \\
\hline Diptera Chironomidae & $2 \pm 2$ & $4 \pm 1$ & 0 & $4 \pm 3$ \\
\hline Diptera Ceratopogonidae & $14 \pm 9$ & $17 \pm 12$ & $1 \pm 1$ & 0 \\
\hline Diptera Chaoboridae & $1 \pm 1$ & $16 \pm 15$ & 0 & $4 \pm 3$ \\
\hline Hemiptera & $19 \pm 17$ & $13 \pm 12$ & $1 \pm 1$ & 0 \\
\hline Total insecta* & $122 \pm 80^{\mathrm{A}}$ & $117 \pm 89^{\mathrm{A}}$ & $34 \pm 39^{\mathrm{B}}$ & $41 \pm 24^{\mathrm{B}}$ \\
\hline Hirudinea & $2 \pm 2$ & $14 \pm 14$ & 0 & 0 \\
\hline Acarina & 0 & $14 \pm 14$ & 0 & 0 \\
\hline Bivalvia & $20 \pm 16$ & $26 \pm 15$ & 0 & 0 \\
\hline Nematoda & $1 \pm 1$ & $24 \pm 17$ & 0 & 0 \\
\hline Animal remains* & $213 \pm 71^{\mathrm{A}}$ & $271 \pm 104^{\mathrm{A}}$ & $6 \pm 3^{\mathrm{B}}$ & $15 \pm 13^{\mathrm{B}}$ \\
\hline Total animal* & $335 \pm 128^{\mathrm{A}}$ & $388 \pm 188^{\mathrm{A}}$ & $40 \pm 92^{\mathrm{B}}$ & $54 \pm 23^{\mathrm{B}}$ \\
\hline Total vegetal* & $152 \pm 30^{\mathrm{A}}$ & $91 \pm 31^{\mathrm{A}}$ & $12 \pm 10^{\mathrm{B}}$ & $10 \pm 5^{\mathrm{B}}$ \\
\hline Total volume* & $510 \pm 142^{\mathrm{A}}$ & $557 \pm 260^{\mathrm{A}}$ & $52 \pm 29^{\mathrm{B}}$ & $66 \pm 38^{\mathrm{B}}$ \\
\hline Total volume: fresh fish biomass & $19.4 \pm 5.0^{\mathrm{A}}$ & $19.1 \pm 5.0^{\mathrm{A}}$ & $21.9 \pm 9.5^{\mathrm{A}}$ & $22.7 \pm 8.2^{\mathrm{A}}$ \\
\hline
\end{tabular}

Total animal $=$ Insecta + Hirudinea + Acarina + Bivalvia + Nematoda + animal remains. Total Vegetal $=$ Plant remains + periphyton

* Indicates $P<0.05$ in the two-way ANOVA between higher and low turbidity. Significant $(P<0.05)$ differences between groups are shown by different letters (A and B)

Mello et al., 2009). However, this difference can be explained by the absence of Cyprinodontiformes species, for instance Cnesterodon decemmaculatus (Jenyns, 1842), which were not registered in the present study. These species may contribute significantly to both lower body length and higher abundance estimations in subtropical shallow lakes (Teixeira-de Mello et al., 2009). The absence of Cyprinodontiformes can be explained by biogeographical aspects and also can be affected by local environmental aspects as the higher connectivity of this shallow lake with fluvial systems.

\section{Final remarks}

We found experimental evidence that the spatial water turbidity gradients and the free-loating plants have a strong impact on the fish community structure by several mechanisms: offering refuges and support food resources.
Our study demonstrates the usefulness of artificial plants for experimental purposes, as already suggested by Meerhoff et al. (2007a), particularly for analyzing the architectural effect of plants on fish community traits, such as trophic group composition, fish body length, species richness, and species abundance. However, species composition differed between natural and artificial plants when water transparency was high, suggesting that fish species can select natural or artificial substrates when the visibility was considerable. Therefore, artificial plants modules should be used with caution in community composition studies, particularly in highly diverse systems. To our knowledge, the present work provides the first comparison of artificial and natural free-floating plant experiments in freshwater ecosystems, and the results are rather promising. We encourage testing of this approach in other systems in order to further establish it applicability for distinguishing between structural effects and other types of interactions between aquatic plants and fish communities. 
Acknowledgments The authors thank Juan Pablo Pacheco and Placiano Lima for field sampling collaboration and Jeater Santos for the wind information. Financial support: Conselho Nacional de Desenvolvimento Científico e Tecnológico (CNPq) Brasil (453919/2012-0, 490675/2010-7), FAPEMAT (484619/ 2011) and DICYT-MEC. VH was partially supported by CNPq (309700/2013-2), TSF by postdoctoral Grant 2010/11269-2, São Paulo Research Foundation (FAPESP) and FTM, NM, and CI were supported by SNI-ANII (Uruguay).

\section{References}

Agostinho, A. A., S. M. Thomaz, L. C. Gomes \& S. L. Baltar, 2007. Influence of the macrophyte Eichhornia azurea on fish assemblage of the Upper Paraná River floodplain (Brazil). Aquatic Ecology 41(4): 611-619.

Aksnes, D. \& L. Giske, 1993. A theoretical model of aquatic visual feeding. Ecological Modelling 67: 233-250.

Bicudo, D. D. C., B. M. Fonseca, L. M. Bini, L. O. Crossetti, C. E. D. M. Bicudo \& T. Araújo-Jesus, 2007. Undesirable side-effects of water hyacinth control in a shallow tropical reservoir. Freshwater Biology 52: 1120-1133.

Britski, H.A., K.Z.S. Silimon \& B.S. Lopes, 2007. Peixes do Pantanal: Manual de Identificação, 2nd edição. EMBRAPA, Brasília: 227pp.

Carniatto, N., R. Fugi, G. Cantanhêde, É. A. Gubiani \& N. S. Hahn, 2012. Effects of flooding regime and diel cycle on diet of a small sized fish associated to macrophytes. Acta Limnologica Brasiliensia 24(4): 363-372.

Carpenter, S. R. \& D. M. Lodge, 1986. Effects of submersed macrophytes on ecosystem processes. Aquatic Botany 26: 341-370.

De Robertis, A., C. H. Ryer, A. Veloza \& R. D. Brodeur, 2003. Differential effects of turbidity on prey consumption of piscivorous and planktivorous fish. Canadian Journal of Fisheries and Aquatic Sciences 60: 1517-1526.

De Tezanos Pinto, P. \& I. O'Farrell, 2014. Regime shifts between free-floating plants and phytoplankton: a review. Hydrobiologia 740(1): 13-24.

Dibble, E. D. \& F. M. Pelicice, 2010. Influence of aquatic plantspecific habitat on an assemblage of small neotropical floodplain fishes. Ecology of Freshwater Fish 19(3): 381-389.

Evangelista, H. B., S. M. Thomaz \& C. A. Umetsu, 2014. An analysis of publications on invasive macrophytes in aquatic ecosystems. Aquatic Invasions 94: 521-528.

Figueiredo, B. R., R. P. Mormul \& E. Benedito, 2015. Structural complexity and turbidity do not interact to influence predation rate and prey selectivity by a small visually feeding fish. Marine and Freshwater Research 66: 170-176.

Gelós, M., F. Teixeira-de Mello, G. Goyenola, C. Iglesias, C. Fosalba, F. García-Rodríguez, J. P. Pacheco, S. García \& M. Meerhoff, 2010. Seasonal and diel changes in fish activity and potential cascading effects in subtropical shallow lakes with different water transparency. Hydrobiolgia 646: 173-185.

Gomes, L., C. Bulla, A. Agostinho, L. Vasconcelos \& L. Miranda, 2012. Fish assemblage dynamics in a Neotropical floodplain relative to aquatic macrophytes and the homogenizing effect of a flood pulse. Hydrobiologia 685(1): 97-107.

González-Bergonzoni, I., M. Meerhoff, T. A. Davidson, F. Teixeira-de Mello, A. Baattrup-Pedersen \& E. Jeppesen, 2012. Meta-analysis shows a consistent and strong latitudinal pattern in fish omnivory across ecosystems. Ecosystems 15(3): 492-503.

Hammer, Ǿ., D. A. T. Harper \& P. D. Ryan, 2001. PAST: paleontological Statistic software package for education and data analysis. Paleontologia Electronica 4(1): 1-9.

Jeppesen, E., J. P. Jensen, M. Søndergaard, T. Lauridsen, L. J. Pedersen \& L. Jensen, 1997. Top-down control in freshwater lakes: the role of nutrient state, submerged macrophytes and water depth. Hydrobiologia 342(343): 151-164.

Junk, W. J., M. T. F. Piedade, J. Schöngart, M. Cohn-Haft, J. M. Adeney \& F. Wittmann, 2011. A classification of major naturally-occurring Amazonian lowland wetlands. Wetlands 31(4): 623-640.

Junk, W., M. Piedade, R. Lourival, F. Wittmann, P. Kandus, L. Lacerda, R. Bozelli, F. Esteves, C. Nunes da Cunha \& L. Maltchik, 2014. Brazilian wetlands: their definition, delineation, and classification for research, sustainable management, and protection. Aquatic Conservation: Marine and Freshwater Ecosystems 24(1): 5-22.

Kottek, M., J. Grieser, C. Beck, B. Rudolf \& F. Rubel, 2006. World Map of the Köppen-Geiger climate classification updated. Meteorologische Zeitschrift 15(3): 259-263.

Loverde-Oliveira, S. \& V. Huszar, 2007. Phytoplankton ecological responses to the flood pulse in a Pantanal lake, Central Brazil. Acta Limnologica Brasiliensia 19(2): 117-130.

Meerhoff, M. \& N. Mazzeo, 2004. Importancia de las plantas flotantes libres de gran porte en la conservación y rehabilitación de lagos someros de Sudamérica. Ecosistemas: http://www.revistaecosistemas.net/pdfs/7.pdf.

Meerhoff, M., N. Mazzeo, B. Moss \& L. Rodríguez-Gallego, 2003. The structuring role of free-floating versus submerged plants in a subtropical shallow lake. Aquatic Ecology 37: 377-391.

Meerhoff, M., J. M. Clemente, F. Teixeira-de Mello, C. Iglesias, A. R. Pedersen \& E. Jeppesen, 2007a. Can warm climaterelated structure of littoral predator assemblies weaken the clear water state in shallow lakes? Global Change Biology 13: $1888-1897$.

Meerhoff, M., C. Iglesias, F. Teixeira-de Mello, J. M. Clemente, E. Jensen, T. L. Lauridsen \& E. Jeppesen, 2007b. Effects of habitat complexity on community structure and predator avoidance behaviour of littoral zooplankton in temperate versus subtropical shallow lakes. Freshwater Biology 52(6): 1009-1021. doi: 10.1111/j.1365-2427.2007.01748.x

Meerhoff, M., F. Teixeira-de Mello, C. Kruk, C. Alonso, I. Gonzalez Bergonzoni, J. P. Pacheco, G. Lacerot, M. Arim, M. Beklioglu \& S. B. Balmana, 2012. Environmental warming in shallow lakes: a review of potential changes in community structure as evidenced from space-for-time substitution approaches. Advances in Ecological Research 46: 259-349.

Miranda, L., M. Driscoll \& M. Allen, 2000. Transient physicochemical microhabitats facilitate fish survival in inhospitable aquatic plant stands. Freshwater Biology 44(4): $617-628$. 
Montiel-Martínez, A., J. Ciros-Pérez \& G. Corkidi, 2015. Littoral zooplankton-water hyacinth interactions: habitat or refuge? Hydrobiologia 1-10.

Nunes, J. R. \& C. J. Da-Silva, 2009. Concentração de íons no sistema de baías chacororé-sinhá mariana, pantanal de mato grosso. UNICIÊNCIAS 13(1).

Pacheco, E. \& C. Da-Silva, 2009. Fish associated with aquatic macrophytes in the Chacororé-Sinhá Mariana lake system and Mutum River, Pantanal of Mato Grosso, Brazil. Brazilian Journal of Biology 69(1): 101-108.

Padial, A. A., S. M. Thomaz \& A. A. Agostinho, 2009. Effects of structural heterogeneity provided by the floating macrophyte Eichhornia azurea on the predation efficiency and habitat use of the small Neotropical fish Moenkhausia sanctaefilomenae. Hydrobiologia 624(1): 161-170.

PCBAP (Programa Nacional do Meio Ambiente, Projeto Pantanal), 1997. Plano de conservação da bacia do Alto Paraguai. Diagnóstico dos meios físico e biótico. Brasília: MMA/PNMA. v.2.

Pekcan-Hekim, Z. \& J. Lappalainen, 2006. Effects of clay turbidity and density of pikeperch (Sander lucioperca) larvae on predation by perch (Perca fluviatilis). Naturwissenschaften 93(7): 356-359.

Pinto, A., 1999. El pulso de inundación y la limnología de la laguna Sinha Mariana en el panatanal de Mato-Grosso, Brasil. Congreso boliviano de limnología y recursos naturales. Revista Boliviana de Ecologia y Conservacion Ambiental 6: 19-26.

Ponce, V. M., 1995. Hydrologic and environmental impact of the Paraná-Paraguay waterway on the Pantanal of Mato Grosso, Brazil: A reference study. San Diego State University.

Sanseverino, A. M., D. Bastviken, I. Sundh, J. Pickova \& A. Enrich-Prast, 2012. Methane carbon supports aquatic food webs to the fish level. PLoS ONE 7(8): e42723.
Sazima, I. \& C. Zamprogno, 1985. Use of water hyacinths as shelter, foraging place, and transport by young piranhas, Serrasalmus spilopleura. Environmental Biology of Fishes 12(3): 237-240.

Scarabotti, P. A., J. A. López \& M. Pouilly, 2011. Flood pulse and the dynamics of fish assemblage structure from neotropical floodplain lakes. Ecology of Freshwater Fish 20(4): 605-618.

Scheffer, M. \& S. R. Carpenter, 2003. Catastrophic regime shifts in ecosystems: linking theory to observation. TRENDS in Ecology and Evolution 18(12): 648-656.

Stoner, A. W., 2004. Effect of environmental variables on fish feeding ecology: implications for the performance of baited fishing gear and stock assessment. Journal of Fish Biology 65: 1445-1471.

Teixeira-de Mello, F., M. Meerhoff, Z. Pekcan-Hekim \& E. Jeppesen, 2009. Substantial differences in littoral fish community structure and dynamics in subtropical and temperate shallow lakes. Freshwater Biology 54: 1202-1215.

Utne-Palm, A. C., 2002. Visual feeding of fish in a turbid environment: physical and behavioural aspects. Marine and Freshwater Behaviour and Physiology 35: 111-128.

Villamagna, A. \& B. Murphy, 2010. Ecological and socioeconomic impacts of invasive water hyacinth (Eichhornia crassipes): a review. Freshwater Biology 55(2): 282-298.

Ximenes, L. Q. L., L. A. D. F. Mateus \& J. M. F. Penha, 2011. Variação temporal e espacial na composição de guildas alimentares da ictiofauna em lagoas marginais do Rio Cuiabá, Pantanal Norte. Biota Neotropica 11(1): 205-215. 